\title{
Additions to the flora of Tenerife (Canary Islands, Spain)
}

\author{
F. VERLOOVE ${ }^{1} \&$ J. A. REYES-BETANCORT ${ }^{2}$ \\ ${ }^{1}$ National Botanic Garden of Belgium, Domein van Bouchout, B-1860 Meise, Belgium \\ ${ }^{2}$ Unidad de Botánica Aplicada (ICIA), Jardín de Aclimatación de La Orotava, Calle Retama 2, \\ E-38400 Puerto de la Cruz, Tenerife, Islas Canarias, España
}

Author for correspondence: J. A. Reyes-Betancort (areyes@icia.es)

Editor: N. Ibáñez

Received 9 June 2011; Accepted 29 July 2011

\begin{abstract}
Additions to the flora of Tenerife (Canary Islands, Spain).- Recent fieldwork in Tenerife, especially in September 2010, yielded several interesting new records of non-native vascular plants. Bothriochloa ischaemum var. songarica, "Asian" Cardamine flexuosa, Cestrum parqui, Digitaria violascens, Ficus lyrata, Ficus rubiginosa, Hoffmannseggia glauca, Hyparrhenia rufa subsp. altissima, Jacaranda mimosifolia, Merremia tuberosa, Passiflora morifolia, Phytolacca dioica, Schefflera actinophylla and Solanum abutiloides are reported for the first time from the Canary Islands, while Eragrostis barrelieri var. pygmaea, Ficus microcarpa, Ipomoea purpurea, Leucaena leucocephala subsp. glabrata, Sechium edule, Tradescantia zebrina and Turnera ulmifolia are new to the flora of the island of Tenerife. New records of Acacia cyclops, Atriplex suberecta, Heliotropium curassavicum, Paspalum dilatatum, P. notatum, Pluchea ovalis, Pulicaria paludosa, Sclerophylax spinescens and Solanum villosum subsp. miniatum confirm their recent expansion on the island of Tenerife. New records are provided for the recently described Sporobolus copei. Finally, Paspalum vaginatum (hitherto possibly confused with $P$. distichum) and Potentilla indica are confirmed from the island of Tenerife.
\end{abstract}

Key words: Canary Islands; chorology; new records; Tenerife; vascular plants.

\section{Resumen}

Adiciones para la flora de Tenerife (Islas Canarias, España).- Algunos recientes trabajos de campo en Tenerife, especialmente en Septiembre de 2010, trajeron consigo varias nuevas e interesantes adiciones de plantas vasculares no autóctonas. Bothriochloa ischaemum var. songarica, Cardamine flexuosa "Asiática", Cestrum parqui, Digitaria violascens, Ficus lyrata, Ficus rubiginosa, Hoffmannseggia glauca, Hyparrhenia rufa subsp. altissima, Jacaranda mimosifolia, Merremia tuberosa, Passiflora morifolia, Phytolacca dioica, Schefflera actinophylla y Solanum abutiloides son citadas por primera vez para las islas Canarias mientras que Eragrostis barrelieri var. pygmaea, Ficus microcarpa, Ipomoea purpurea, Leucaena leucocephala subsp. glabrata, Sechium edule, Tradescantia zebrina y Turnera ulmifolia son nuevas para la flora de la isla de Tenerife. Nuevas localidades para Acacia cyclops, Atriplex suberecta, Heliotropium curassavicum, Paspalum dilatatum, P. notatum, Pluchea ovalis, Pulicaria paludosa, Sclerophylax spinescens y Solanum villosum subsp. miniatum confirman su reciente expansión en la isla de Tenerife. También se recogen nuevas localidades para el recientemente descrito Sporobolus copei. Finalmente, se confirma para la isla de Tenerife Paspalum vaginatum (hasta ahora posiblemente confundido con $P$. distichum) y Potentilla indica.

Palabras clave: corología; islas Canarias; nuevas citas; plantas vasculares; Tenerife. 


\section{INTRODUCTION}

The vascular flora of the Canary Islands in general and the island of Tenerife in particular has been the subject of numerous publications in the past. Eriksson et al. (1974) provided a checklist for the whole of Macaronesia and chorological, taxonomical and nomenclatural updates were regularly published subsequently (see for instance Hansen \& Sunding, 1993). A similar checklist, but this time restricted to the Canary Islands, was recently published by Acebes Ginovés et al. (2004, 2010). Finally, Sanz-Elorza et al. (2005) elaborated a list with invasive and potentially invasive vascular plant species in the Canary Islands.

Despite this previous research on the flora of the Canary Islands, new data still come to light. Particularly the non-native flora is obviously still imperfectly known and the number of new introductions (deliberate as well as accidental) still seems on the increase. In the present paper new records are presented for species that are either new to the Canary Islands (or even Macaronesia) or new to the island of Tenerife. For some species that were recently detected for the first time in Tenerife, additional new records are provided.

The majority of the taxa in the present paper has probably escaped from cultivation (and was initially introduced on purpose, often as ornamentals). However, there is also an increasing number of weeds that were recently unintentionally introduced in irrigated lawns (see also Siverio-Núñez et al., 2011).

\section{MATERIALS AND METHODS}

The actual presence or absence on the Island of Tenerife of the taxa here presented was each time compared with data provided by Hohenester \& Welss (1993) and Acebes-Ginovés et al. (2004, 2010). For some recently introduced species several additional papers were checked as well.

All taxa are presented in alphabetical order. Each entry includes the scientific name of the taxon (if useful accompanied by one or more synonyms), the family to which the taxon belongs (see below), kind of chorological novelty and estimated degree of naturalization (sensu Richardson et al., 2000), enumeration of herbarium collections, origin of the taxon and details about its secondary distribution and, finally, information on its actual occurrence in the island of Tenerife.

Familial and generic classifications are in accordance with APGIII (2009). For the taxa treated here this means that Mimosaceae are included in Leguminosae, Chenopodiaceae in Amaranthaceae and Turneraceae in Passifloraceae.

Voucher specimens of all taxa are preserved in the public herbaria of Jardín de Aclimatación de La Orotava (ORT) and/or National Botanic Garden of Belgium (BR). Duplicates were often deposited in other relevant herbaria (mainly TFC) or in the private herbarium of the first author.

\section{RESULTS AND DISCUSSION}

\section{Taxonomic part}

Acacia cyclops A. Cunn. ex G. Don, Gen. Hist. 2: 404 (1832)

(Leguminosae s. l., incl. Mimosaceae)

New records of a recently discovered species to the flora of Tenerife. Naturalized - invasive.

Spain, Tenerife: Taganana, TF134 towards Almáciga, barranco, dry, gravelly riverbed, close to the sea, dense monospecific stand of $c a .30 \mathrm{~m}^{2}, 12.09 .2010$, F. Verloove 8473 (BR).

Native to southwestern Australia. Widely cultivated as an ornamental in many warm-temperate and subtropical regions of the world. Reported as an invasive environmental weed in South Africa (Mabberley, 2008). In the Iberian Peninsula locally naturalized (mainly in coastal regions) in the Levante in Spain and western Portugal (Paiva, 1999). In Portugal Acacia cyclops locally behaves as an invasive environmental weed (Marchante et al., 2008).

In the Canary Islands thus far only known from the easternmost islands Gran Canaria, Fuerteventura and Lanzarote (Acebes-Ginovés et al., 2004) and more recently also from Tenerife (Acebes-Ginovés et al., 2010). Indeed, Acacia cyclops is not rare in Tenerife. In addition to the dense, monospecific stand in Taganana (see above) it was furthermore observed in Santa Cruz (Barranco de Santos), Adeje (dense stand in barranco, close to the junction of 
TF82 and TF1-motorway), Las Américas (barranco close to Parque Central de Arona), Los Palos (barranco de Las Galletas), etc.

Acacia cyclops is easily distinguished by the presence of a colourful (dark reddish) aril surrounding the seed (Kodela \& Tindale, 2001).

Atriplex suberecta I. Verd. in Bothalia 6: 418 (1954) (Amaranthaceae)

New records of a recently introduced species to the flora of Tenerife. Naturalized.

Spain, Tenerife: Puerto de la Cruz, Muelle (port), close to the lighthouse, ruderal area close to the sea, common, 05.09.2010, F. Verloove 8441 (BR, ORT 4733); Güímar, polígono industrial El Socorro, sandy ruderal area close to the sea, common, 11.09.2010, F. Verloove 8431 (BR).

Native to Australia (George, 1984). Locally naturalized and increasing in warm-temperate regions of the world (Mediterranean area, South Africa). In the Iberian Peninsula initially recorded in the province of Alicante (Castroviejo, 1990); soon afterwards also in the provinces of Jaen, Murcia and Valencia (cf. www.anthos.es).

Hohenester \& Welss (1993) and Acebes-Ginovés et al. (2004) merely cited Atriplex suberecta from Gran Canaria and Fuerteventura. However, Reyes-Betancort et al. (2000) added further records from Lanzarote and Tenerife. In 2010 Atriplex suberecta was confirmed in abundance at its original locality of introduction in Tenerife (muelle pesquero in Puerto de la Cruz). In Güímar (polígono industrial El Socorro) it grows in identical circumstances (bare, sandy ruderal areas close to the sea) and in equal abundance. Finally, Atriplex suberecta was also recorded (s.c.) in small number in the port area of Santa Cruz, on sandy waste land near the Golf Court of Adeje and in a demolished plant nursery in El Puertito de Güímar (personal observations first author in September 2010).

Despite its recent arrival in Tenerife, Atriplex suberecta appears to be a fast spreading weed. However, it always seems confined to heavily disturbed habitats and probably is not harmful to native vegetation.
Bothriochloa ischaemum (L.) Keng in Contr. Biol. Lab. Sci. Soc. China, Bot. Ser. 10: 201 (1936)

var. songarica (Rupr. ex Fisch. \& C. A. Mey.) Celarier \& J. R. Harlan in Bot. J. Linn. Soc. 55 (363): 758 (1958)

(Poaceae)

New to the flora of the Canary Islands. Naturalized.

Spain, Tenerife: Fasnia, Barranco del Canal, dry, gravelly riverbed, scattered specimens, 09.05.2009, F. Verloove 7906 (priv. herb. FV, dupl. TFC); Ibid., 23.02.2009, M. A. Padrón-Mederos (ORT 41470); Ibid., above the junction between La Caleta-Punta Prieta and TF1-motorway, sunny slope of a small ravine, 11.11.2010, J. A. Reyes-Betancort (ORT 41719, 41720).

Variety songarica is probably native to China (Vega, 2000). It is naturalized in parts of the New World (Bolivia, Caribbean, Colombia, Costa Rica, Guyana, Mexico, United States and Venezuela according to Zuloaga et al., 2003) and doubtlessly elsewhere. It is often merely included in the synonymy of Bothriochloa ischaemum (see for instance Allred, 2003). However, Celarier \& Harlan (1958) already demonstrated that both are morphologically, chorologically and cytologically distinct.

Variety songarica differs from var. ischaemum in having pubescent nodes (with hairs up to $1 \mathrm{~mm}$ long) and leaf blades. Its sessile spikelets are never pitted (occasionally pitted in var. ischaemum). This taxon is very reminiscent of Dichanthium annulatum (Forssk.) Stapf. The latter was recently reported from the very same locality (Cruz-Trujillo et al., 2008). A recent revision of the material in TFC has demonstrated that both taxa have been confused in Tenerife and that Dichanthium annulatum should be removed from the floristic inventory of Tenerife. From this species Bothriochloa ischaemum var. songarica is readily distinguished by its sterile pedicellate spikelets (vs. staminate) and by glumes of the sessile spikelet lacking conspicuous bulbousbased hairs on the margin.

The residence status of Bothriochloa ischaemum var. songarica in Tenerife seems unequivocal: given its origin, it is at most a naturalized xenophyte (Cruz-Trujillo et al., 2008 suggested native status for "Dichanthium annulatum"). This variety is widely cultivated as a forage grass (mostly under 
its cultivar name "King Ranch Bluestem") which possibly explains its occurrence in Tenerife.

Hohenester \& Welss (1993) questioned the presence of Bothriochloa ischaemum (doubtlessly var. ischaemum) in the Canary Islands ("T?", "C?"). The species was not upheld by Acebes-Ginovés et al. (2004, 2010). Press \& Short (1994) also doubt its presence in Madeira.

Cardamine flexuosa auct. non With.

(syn.: "Asian" Cardamine flexuosa)

(Brassicaceae)

New to the flora of the Canary Islands. Ephemeral (?).

Spain, Tenerife: Bajamar, TF13 close to Barranco Perdomo, Pelargonium-plantation (irrigated) in roundabout, weed, 15.09.2010, F. Verloove 8433 (ORT 41743).

Native to southeastern Asia. Probably widely naturalized as an agricultural and horticultural weed in many parts of the world but still very poorly known and doubtlessly largely overlooked. At present known from Australia, Europe and North America (Lihová et al., 2006; Bleeker et al., 2008).

This critical Asian species of Cardamine, for which no appropriate name has been found/proposed so far, belongs to a critical group of weedy, annual (or short-lived perennial) species. From this complex only Cardamine hirsuta L. has been recorded so far in the Canary Islands (Hohenester \& Welss, 1993; Acebes-Ginovés et al., 2004, 2010), although previous confusion with "Asian" $C$. flexuosa cannot be ruled out. In general appearance this enigmatic taxon is reminiscent of Cardamine flexuosa but it is subglabrous and its leaflets are, at least in part, trilobed. From Cardamine hirsuta it is furthermore distinguished by the absence of a basal leaf rosette.

The origin of "Asian" Cardamine flexuosa in Tenerife is uncertain. However, in western Europe (for instance in Belgium; first author's pers. obs.) it is a rather regular weed in plant nurseries. It is very likely that it is widely dispersed as a weed of container plants in many other parts of the world. Near Bajamar it was found among recently planted Pelargonium-plants, which also suggests an introduction via plant nurseries.
Cestrum parqui L’Hér., Stirp. Nov. 73 (1788)

(Solanaceae)

New to the flora of the Canary Islands. Naturalized - invasive.

Spain, Tenerife: Puerto de la Cruz, Barranco Martiánez, dry, gravelly riverbed, abundantly naturalized, 05.09.2010, F. Verloove 8448 (ORT 41737); Puerto de la Cruz, Barranco San Nicolás, 03.06.2010, J. A. Reyes-Betancort \& M. A. PadrónMederos (ORT 41703, 41704).

Native to South America (Chile). Widely cultivated as an ornamental in warm-temperate and subtropical regions of the world. At present Cestrum parqui is increasingly reported as an escape from cultivation in southwestern Europe (France, Italy, Portugal, Spain; see for instance Conti et al., 2005; Verloove \& Sánchez-Gullón, 2008).

Cestrum parqui is surprisingly omitted in Hohenester \& Welss (1993) and Acebes-Ginovés et al. (2004, 2010). At least in the surroundings of Puerto de la Cruz and Los Realejos it is a rather frequent and well-established xenophyte in dry, gravelly riverbeds (barrancos). In Puerto de la Cruz, it was not only recorded in Barranco Martiánez and Barranco San Nicolás (see above) but also in Barranco Tafuriaste (September 2010). Near Los Realejos Cestrum parqui is abundantly naturalized in several barrancos (for instance close to TF5, TF334, ...; September 2010). It often exhibits the same invasive behaviour as (the superficially similar) Nicotiana glauca Graham. Its potential invasiveness was already stressed before in the Iberian Peninsula (Sanz-Elorza et al., 2001).

Rodríguez-Pérez (1998) cited Cestrum aurantiacum Lindl. and C. nocturnum L. as ornamentals in the Canary Islands, but not C. parqui. However, its cultivation is documented since at least 1879 (Benítez-de-Lugo \& Wildpret, 1879).

Digitaria violascens Link, Hort. Berol. 1: 229 (1827) (Poaceae)

New to the flora of the Canary Islands. Naturalized.

Spain, Tenerife: Puerto de la Cruz, Playa Jardín, parque, lawn weed, also foot of wall, abundant, 
07.09.2010, F. Verloove 8476 (BR, ORT 41730); La Orotava, Av. Républica de Venezuela, parque, lawn weed, 10.09.2010, F. Verloove 8478 (BR); Puerto de la Cruz, Jardines Taoro, lawn weed, 17.09.2010, F. Verloove 8497 (BR, ORT 41731).

Native to tropical Asia. Widely naturalized as a weed of arable land and turf in many warm-temperate and (sub-) tropical regions of the world (Africa, Americas, and Australia). Either long neglected or a recent newcomer in the Mediterranean area (Verloove, 2008; Verloove \& Sánchez-Gullón, 2008; Pyke, 2008). So far, known at least from southern France, Italy and Spain but doubtlessly overlooked elsewhere.

In Tenerife Digitaria violascens was repeatedly collected in September 2010 in irrigated (public) lawns in the surroundings of Puerto de la Cruz and La Orotava. It should be looked for in other places (and other islands) in similar habitats. For more information on its distinction and distribution in southwestern Europe, see Verloove (2008).

Eragrostis barrelieri Daveau in J. Bot. (Morot) 8: 289 (1894)

var. pygmaea (Daveau) Dobignard \& Portal, Eragrostis France \& Europe Occid.: 175 (2002)

(Poaceae)

New to the flora of Tenerife. Probably native.

Spain, Tenerife: El Médano, weed along the road close to La Tejita, 02.2011, J. A. Reyes-Betancort (ORT 41756, BR).

Probably a North African element reaching the Iberian Peninsula (cf. Scholz in Greuter \& Raus, 2005).

This variety was recently recorded for Fuerteventura (Otto \& Scholz in Greuter \& Raab-Straube, 2009). In Tenerife Eragrostis barrelieri var. pygmaea is associated with dry habitats while the typical variety rather prefers more damp places. Differences between these two varieties are not clear in the Canary Islands. Variety pygmaea is usually distinguished by its dwarf growth (plants rarely exceeding 9 $\mathrm{cm}$ ), small inflorescences (up to $3.5 \mathrm{~cm}$ long) and small brownish spikelets up to $6.5 \mathrm{~mm}$ long (Portal, 2002). However, in the Canary Islands plants with intermediate features have been observed.
Moreover, plant size and inflorescence dimensions seem to be chiefly affected by ecological factors. Variety pygmaea may possibly be a mere ecotype of Eragrostis barrelieri.

Ficus lyrata Warb. in Bot. Jahrb. Syst. 20: 172 (1894) (Moraceae)

New to the flora of the Canary Islands. Ephemeral. Spain, Tenerife: Buenavista del Norte, centro ciudad, barranco, 1x ( $c a .250 \mathrm{~cm}$ tall), subspontaneous, 17.09.2010, F. Verloove 8411 (ORT 41748).

Native to tropical West Africa. Widely cultivated as an ornamental (outdoors) in subtropical regions of the world (and much more widely indoors).

In the Canary Islands Ficus lyrata is a common ornamental plant but it apparently has not been recorded yet outside of cultivation (Hohenester \& Welss, 1993 and Acebes-Ginovés et al., 2010). In a gully in the center of Buenavista del Norte a young, obviously "wild" plant was recorded in September 2010.

Ficus microcarpa L. f., Suppl. Pl. 442 (1782)

(Moraceae)

New to the flora of Tenerife. Ephemeral.

Spain, Tenerife: Puerto de La Cruz, surroundings of Hotel Botánico, epiphyte on Phoenix canariensis Chabaud, spontaneous, 17.04.2011, J. A. ReyesBetancort (ORT 41757, BR).

Native to Southern Asia (from Ceylon to Australia). Widely cultivated as an ornamental (outdoors) in subtropical regions of the world.

In the Canary Islands Ficus microcarpa is a common ornamental plant in streets and squares. Montelongo-Parada (1996) already reported about its naturalization in Gran Canaria, which was enabled after the introduction of its pollinator wasp Eupristina verticillata Waterston (Báez, 1998). However, this record apparently remained unnoticed by subsequent authors (Hohenester \& Welss, 1993; Acebes-Ginovés et al., 2010). In addition to the records from Puerto de la Cruz (also in Parque Taoro) Ficus microcarpa was furthermore observed 
in Santa Cruz, growing in small cracks and joints of buildings, sidewalks, pavements, etc. (second author's pers. obs.).

Ficus rubiginosa Desf. ex Vent., Jard. Malmaison 114 (1805)

(Moraceae)

New to the flora of the Canary Islands. Ephemeral.

Spain, Tenerife: Puerto de La Cruz, surroundings of Botanic Garden, epiphyte on Phoenix canariensis, 17.04.2011, J. A. Reyes-Betancort (ORT 41758, BR).

Native to East Australia (Queensland and New South Wales) (Dixon et al., 2001). Widely cultivated as an ornamental (outdoors) in subtropical regions of the world.

In the Canary Islands Ficus rubiginosa is a common ornamental plant but it apparently has not been recorded yet outside of cultivation (Hohenester \& Welss, 1993 and Acebes-Ginovés et al., 2010). In the surroundings of the Botanic Garden and the Hotel Botánico at Puerto de La Cruz it is more or less frequent as an epiphyte on Phoenix canariensis (rare as a lithophyte).

Heliotropium curassavicum L., Sp. P1. 130 (1753) (Boraginaceae)

New records of a recently introduced species to the flora of Tenerife. Naturalized.

Spain, Tenerife: Adeje, close to Campo Golf de Adeje, sandy ruderal roundabout, close to the sea, scattered small populations, $14.09 .2010, F$. Verloove 8426 (ORT 41745).

Native to South America and southern North America. Widely naturalized and often weedy in many warm-temperate regions of the world, including large parts of the Mediterranean area (Brummitt, 1972). In the Iberian Peninsula Heliotropium curassavicum is rather frequent in (predominantly) coastal habitats in the Levante and, to a lesser extent, in Andalucía (Sanz-Elorza et al., 2004).

In the Canary Islands Heliotropium curassavicum was long restricted to the island of Fuerteventura
(Hohenester \& Welss, 1993; Sanz-Elorza et al., 2004; Acebes-Ginovés et al., 2004). Padrón-Mederos et al. (2007) recently reported on its discovery in Tenerife: Los Cristianos (since 1996) and Los Abrigos (since 2004).

In September 2010 Heliotropium curassavicum was recorded several times but always in small number in bare, sandy habitats close to the sea in the surroundings of the Golf Court in Adeje.

Hoffmannseggia glauca (Ortega) Eifert in Sida 5: 43 (1972)

(Leguminosae s. l., Caesalpiniaceae)

New to the flora of the Canary Islands. Ephemeral.

Spain, Tenerife: Santa Cruz, the Palmetum, 24.11.2006, J. A. Reyes-Betancort \& M. A. PadrónMederos (ORT 41760).

Native to regions extending from the southwestern United States to Chile and Argentina. In the Iberian Peninsula Hoffmannseggia glauca has been recorded before in the provinces of Alicante and Málaga (see Cabezudo et al., 2009 for an overview).

A few plants were observed in November 2006 in the Palmetum, growing around the base of a palm. Given its reputation as an environmental weed, after its determination plants were eradicated (comm. Carlo Morici).

Hyparrhenia rufa (Nees) Stapf, Fl. Trop. Afr. 9: 304 (1919) subsp. altissima (Stapf) B. K. Simon in Austrobaileya 3 (1): 86 (1989)

(syn.: H. altissima Stapf)

New to the flora of the Canary Islands. Naturalized.

Spain, Tenerife: Puerto de la Cruz, El Durazno, close to Barranco Martiánez, roadside, locally, 10.09.2010, F. Verloove 8571 (BR); La Orotava, El Ramal, roadside, 05.11.2010, J. A. Reyes-Betancort (ORT 41759); Ibid., bajo El Calvario, roadside, 05.11.2010, Ejusd. (ORT 41760).

Native to tropical Africa, possibly originally confined to its northeastern parts (type from Ethiopia). 
Hyparrhenia rufa is a rare but locally naturalized xenophyte in the Canary Islands, although it is restricted to Tenerife (Hansen, 1971; Hansen, 1975). It is readily distinguished from native Hyparrhenia hirta (L.) Stapf and H. sinaica (Delile) Llauradó ex G. López by its rufously hairy spikelets (whitish hairy in the latter two). However, some populations of Hyparrhenia rufa from the surroundings of Puerto de la Cruz markedly differ from typical ones: they have much longer spatheoles, longer racemes that are always ultimately reflexed, a longer upper raceme-base and (much) larger spikelets. This particular combination of characters corresponds well with the circumscription of Hyparrhenia altissima Stapf, a species that is now usually included in the synonymy of $H$. rufa (see for instance Clayton \& Renvoize, 1982; Phillips, 1995). An isotype at Kew of Hyparrhenia altissima (made from plants cultivated at Karlsruhe from seed sent by Schimper from Ethiopia) is a little younger (racemes not yet reflexing) but is otherwise a good match with material from Tenerife: spatheole $8 \mathrm{~cm}$, racemes $5.5-6 \mathrm{~cm}$, sessile spikelet $5.5 \mathrm{~mm}$, etc. (comm. S. Phillips, April 2011).

Simon (1989) made the new combination $H$. rufa subsp. altissima for aberrant Australian plants of $H$. rufa. These differ by their villous peduncles and more pallid spikelet indumentum, but not on size differences. Whilst Australian plants apparently lie at the upper end of the normal size range, they are not a particularly good match with the Tenerife collections and the subspecies name altissima is obviously misapplied in Australia.

Hyparrhenia rufa subsp. altissima seems to have been present in the surroundings of Puerto de la Cruz for over 40 years. It was already collected by Alfred Hansen (K) on 23 October 1970 with the following locality details: "on roadside between Puerto de la Cruz and Santa Ursula, Tenerife (A giant plant, some specimens attaining a height of ca. 2 m)" (comm. S. Phillips, April 2011).

Ipomoea purpurea (L.) Roth, Bot. Abh. Beobacht. 27 (1787)

(Convolvulaceae)

New to the flora of Tenerife. Ephemeral (?).

Spain, Tenerife: Santa Ursula, Barranco de la Hoya (close to TF217), adjacent to a path in a ravine, ru- deral, few plants, 06.09.2010, F. Verloove 8446 (ORT 41735); Road from El Socorro to El Portezuelo, 370 $\mathrm{m}, 17.07 .2005$, J. A. Reyes-Betancort (ORT 39745); Ibid., 09.03.2004, A. Santos-Guerra (ORT 40423).

Native to tropical America. Widely naturalized in warm-temperate and subtropical regions of the world. Ipomoea purpurea is cultivated as an ornamental but also occurs as an agricultural weed. In the Iberian Peninsula it is reported as an invasive xenophyte especially in eastern Spain (Sanz-Elorza et al., 2004).

In the Canary Islands Ipomoea purpurea was hitherto only known from Gran Canaria (Hohenester \& Welss, 1993; Sanz-Elorza et al., 2004; Acebes-Ginovés et al., 2004, 2010). The present records appear to be the first for the island of Tenerife. Elsewhere in Macaronesia, for instance in Madeira (Press \& Short, 1994), it is a frequently naturalized weed.

Jacaranda mimosifolia D. Don in Bot. Reg. 8: t. 631 (1822)

(Bignoniaceae)

New to the flora of the Canary Islands. Ephemeral.

Spain, Tenerife: Puerto de la Cruz, close to Barranco Tafuriaste, crack in pavement, two juvenile plants (self-sown, planted in the vicinity), 05.09.2010, F. Verloove 8450 (ORT 41738).

Native to South America (Argentina, Bolivia). More or less widely cultivated as an ornamental tree in warm-temperate and subtropical regions of the world.

In the Canary Islands Jacaranda mimosifolia is a rather common ornamental tree (especially along streets) but it has apparently not been recorded yet outside of cultivation (Hohenester \& Welss, 1993; Acebes-Ginovés et al., 2004, 2010). In September 2010 two saplings were recorded on pavement (cracks in concrete) in Puerto de la Cruz (doubtlessly merely ephemeral).

\section{Leucaena leucocephala (Lam.) de Wit in Taxon} 10: 54 (1961)

subsp. glabrata (Rose) Zárate in Phytologia 63(4): 305 (1987)

(syn.: L. glabrata Rose) 
(Leguminosae s.l., incl. Mimosaceae)

New to the flora of Tenerife. Naturalized - invasive.

Spain, Tenerife: Santa Maria del Mar (Añaza), barranco, locally naturalized, 16.09.2010, $F$. Verloove 8414 (ORT 41750).

Native to tropical South America and southern North America. Widely cultivated as an ornamental in warm-temperate and subtropical regions of the world. Increasingly reported as a troublesome environmental weed, recently also in the Mediterranean area (for instance in palm plantations in Israel; Raimondo \& Domina, 2007). In the Iberian Peninsula Leucaena leucocephala is still rare and confined to coastal areas in the Levante and Andalucia (Dana et al., 2003; Sanz-Elorza et al., 2004; Herrero-Borgoñón, 2007).

In the Canary Islands Leucaena leucocephala was restricted for a long time to Gran Canaria (Hohenester \& Welss, 1993; Sanz-Elorza et al., 2004; Acebes-Ginovés et al., 2004). However, it was recently further reported from El Hierro, La Gomera and Lanzarote as well (Padrón-Mederos et al., 2009). In September 2010 it was recorded on several occasions in Tenerife, apparently for the first time. In the surroundings of Añaza (Santa María del Mar) Leucaena leucocephala is perfectly established in at least two barrancos. It was furthermore observed in similar habitats in Tacoronte (waste land in city center), Los Naranjeros (Barranco de Las Lajas) and Los Silos (Barranco de Cuevas Negras). Elsewhere in Macaronesia, for instance in Madeira (Press \& Short, 1994), it is apparently more frequently naturalized.

All populations seen so far in the Canary Islands seem to pertain to subsp. glabrata (see also PadrónMederos et al., 2009). This subspecies is chiefly characterized by its taller habit and larger leaves and inflorescences (see Hughes, 1998 for details). It is the usual taxon in cultivation (Hughes, 1998).

Merremia tuberosa (L.) Rendle, Fl. Trop. Afr. 4(2): 104 (1905)

(Convolvulaceae)

New to the flora of the Canary Islands. Naturalized (?).

Spain, Tenerife: Las Américas, Parque Central de
Arona, foot of tree (Ficus spec.), 1x, self-sown (non-flowering), 16.05.2009, F. Verloove 8494 (BR); Ibid., 14.09.2010, F. Verloove 8511 (ORT 41755); Buenavista del Norte, NE-side of Golf Court, invading barranco from a nearby plantation, monospecific stand, 17.09.2010, F. Verloove 8499 (BR).

Native to tropical America, extending to Mexico. Widely introduced in the tropics as an ornamental vine (Hyam, 2000), also in the Canary Islands (Rodríguez-Pérez, 1998). Occasionally reported as an escape from cultivation, for instance in Central Africa (Lejoly \& Lisowski, 1992) and India (Chandra, 1982).

In the past years Merremia tuberosa has been recorded twice in Tenerife. A single, obviously recently germinated sapling grows at the foot of a Ficus-tree in the Parque Central de Arona in Las Américas. In Buenavista del Norte Merremia tuberosa invades a barranco, apparently as an "escape" from an adjoining, neglected plantation. It has probably not been recorded before in the wild in Macaronesia.

A more or less similar species from the same genus (the annual and hirsute hairy Merremia aegyptia (L.) Urban) is known from the Cape Verde Islands (Gonçalves, 1996).

Paspalum dilatatum Poir. in Lam., Encycl. 5: 35 (1804)

(Poaceae)

New records of a recently introduced species to the flora of Tenerife. Naturalized.

Spain, Tenerife: Puerto de la Cruz, Playa Jardín (parque), lawn weed, 07.09.2010, F. Verloove 8451 (BR, ORT 41739).

Native to South America (Brazil to Argentina). Widely naturalized in warm-temperate and (sub-) tropical regions of the world (Africa, Asia, Australia, Europe). Initially introduced as a forage grass and now a troublesome weed of agricultural fields and lawns. A locally rather common species in many coastal areas of the Iberian Peninsula and often considered to be an invasive weed (Sanz-Elorza et al., 2004).

In the Canary Islands apparently much rarer and 
for a long time solely known from Gran Canaria and La Palma (Hohenester \& Welss, 1993; SanzElorza et al., 2004; Acebes-Ginovés et al., 2004). More recently it was also reported for the first time from Tenerife (Acebes-Ginovés et al., 2010) where it probably has been widely overlooked so far, especially as a weed in lawns. In addition to the collection cited above, Paspalum dilatatum was frequently recorded in September 2010 in public lawns, for instance in Puerto de la Cruz (Parque Sortija, TF312 near Barranco San Felipe, at Centro Commercial La Cúpula), Santa Cruz (close to the Palmetum, with $P$. notatum), ... Paspalum dilatatum is furthermore widely dispersed along road verges in the Anaga Parque Rural, for instance at the junction of TF12 and TF143 (Las Mercedes, Parque Rural Anaga), near Cruz del Carmen (TF12), at the junction of TF12 and TF114, etc. In all places, it appears to be fully established and its future spread is predictable. Elsewhere in Macaronesia, for instance in Madeira (Press \& Short, 1994), it is apparently more commonly naturalized.

\section{Paspalum notatum Flüggé, Gram. Monogr., Paspalum 106 (1810) \\ var. saurae Parodi in Revista Argent. Agron. 15: 55 (1948) \\ (syn.: P. saurae (Parodi) Parodi) \\ (Poaceae)}

New records of a recently introduced species to the flora of Tenerife. Naturalized.

Spain, Tenerife: Puerto de la Cruz, Punta de las Carretas, lawn weed, 05.09.2010, F. Verloove 8447 (ORT 41736); Santa Cruz, close to the Palmetum, lawn weed, with $P$. dilatatum, 08.09.2010, F. Verloove 8452 (BR, ORT 41740).

Native to Central and South America. Widely introduced elsewhere in warm-temperate regions and the tropics for forage, turf or erosion control and readily escaping (Africa, Asia, Australia and more recently also in Europe). In the Iberian Peninsula Paspalum notatum var. saurae has been recorded in the provinces of Alicante, Barcelona, Gerona and Valencia (Verloove, 2003; 2005), Zaragoza (Pyke, 2003) and more recently also in Huelva (comm. E. Sánchez-Gullón).
Paspalum notatum was recorded recently for the first time from the Canary Islands by SiverioNúñez et al. (2011). Here we confirm that these plants belong to var. saurae. This taxon has narrower leaves (0.2-0.4 mm wide) and smaller spikelets (2.8-3.2 $\mathrm{mm}$ long and 2-2.2 mm wide) than the typical variety (Zuloaga et al., 2004). It obviously is a recent introduction in grass seed mixtures and now regularly occurs in public and private lawns, at least in Tenerife. In September 2010 it was not only observed in Puerto de la Cruz and Santa Cruz (see above) but also in Güímar (lawn in Polígono Industrial El Socorro), Las Américas (lawn close to Parque Central de Arona) and other localities.

\section{Paspalum vaginatum Sw., Prodr. 21 (1788)}

\section{(Poaceae)}

Confirmation for the flora of Tenerife. Naturalized.

Spain, Tenerife: Santa Cruz, close to the port, tramway, lawn weed, 08.09.2010, F. Verloove 8438 (BR); Buenavista del Norte, golf court, weed in turf, 17.09.2010, F. Verloove 8415 (ORT 41749).

Native to Tropics. Widely naturalized and often an invasive environmental weed in warm-temperate and (sub-) tropical regions of the world (including the Mediterranean area).

Most checklists and floras dealing with the Canary Islands possibly erroneously refer to this species as Paspalum distichum L. (Hohenester \& Welss, 1993; Acebes-Ginovés et al., 2004). Paspalum distichum is the correct name for $P$. paspalodes (Michaux) Thell. Hansen (1971) already reported on the presence of both Paspalum distichum and $P$. vaginatum in the Canary Islands, at least in Tenerife. Genuine Paspalum vaginatum is here confirmed once again from Tenerife. It is mostly found in irrigated lawns and might have been introduced unintentionally (as a contaminant) or on purpose: according to Allen \& Hall (2003) Paspalum vaginatum is sometimes grown for turf or in lawn trials.

However, the presence of "true" Paspalum distichum in the Canary Islands cannot be totally ruled out. Additional herbarium revisions are required to solve the taxonomy of this group in the area. 
Passiflora morifolia Mast. in Mart., Fl. Bras. 13(1): 555 (1872)

(Passifloraceae)

New to the flora of the Canary Islands. Naturalized.

Spain, Tenerife: Puerto de la Cruz, Jardín Botanico, invasive weed, 10.09.2010, F. Verloove \& J. A. Reyes-Betancort 8500 (BR, ORT 41763); Ibid., 02.10.2010, J. A. Reyes-Betancort (ORT 41764); Santa Cruz de Tenerife, the Palmetum, 24.11.2006, M. A. Padrón-Mederos et al. (ORT 40784).

Native to Central and South America (mainly Argentina, Bolivia, Brazil and Paraguay). Sporadically introduced as an ornamental vine in Africa, Asia, Australia, North America and the West Indies (MacDougal, 1994; Ulmer \& MacDougal, 2004). Sometimes escaping but never becoming a noxious weed (MacDougal, 2004). Also cultivated as an ornamental in Europe (Miller, 1997, often erroneously as Passiflora bryonioides H. B. K.) but probably not recorded so far as an escape from cultivation. In the Mediterranean area it is known as a naturalized weed from Israel (Joel \& Liston, 1986).

Passiflora morifolia is a rather frequent and undesirable weed in the Botanic Garden and its surroundings in Puerto de la Cruz.

Phytolacca dioica L., Sp. P1., ed. 2, 1: 632 (1762)

(Phytolaccaceae)

New to the flora of the Canary Islands. Naturalized (?).

Spain, Tenerife: Puerto de la Cruz, Barranco Martiánez, dry, gravelly riverbed, close to the sea, abundantly escaping from cultivation, 05.09.2010, F. Verloove 8423 (ORT 41744).

Native to South America. Widely cultivated as an ornamental tree in warm-temperate and subtropical regions of the world, including the Mediterranean area. Known as an escape from cultivation since quite some time in southwestern Europe (Webb, 1964).

In the Canary Islands Phytolacca dioica is commonly cultivated as an ornamental in public and private gardens. It regularly escapes and is locally perfectly naturalized, for instance in Barranco Martiánez in Puerto de la Cruz. Its incipient escape was also reported from Madeira (Press \& Short, 1994) and Lobin (1982) added Phytolacca dioica for the Cape Verde Islands (without further comments).

Pluchea ovalis (Pers.) DC., Prodr. 5: 450 (1836)

(Asteraceae)

New records of a recently introduced species to the flora of Tenerife. Naturalized - invasive.

Spain, Tenerife: Playa de Las Américas, near Siam Park, vacant lot (ruderal), one shrub, 14.05.2009, F. Verloove 7571 (priv. herb. FV, dupl. B, BR, LG); Adeje, close to the junction of TF82 and TF1-motorway, barranco, dry, gravelly riverbed, abundantly sowing, 14.09.2010, F. Verloove 8455 (BR, ORT 41741).

Native to Africa, Cape Verde Islands, Arabian Peninsula (King-Jones, 2001).

Pluchea ovalis has been recorded in Tenerife since 2007 (see Padrón-Mederos et al., 2009 for details). Despite being relatively recently introduced as an ornamental at the Campo Golf in Adeje it has obviously been able to spread in a very fast way, and now occurs in numerous localities between Adeje and Las Américas. The concerns expressed by Padrón-Mederos et al. (2009) about its potential invasive behaviour seem to be confirmed. This is rather surprising since it occurs in similar habitats and apparently as a non-weedy native species in the Cape Verde Islands (Heim, 1984).

Potentilla indica (Andrews) T. Wolf in Ascherson \& Graebner, Syn. Mitteleur. Fl. 6(1): 64 (1904) (syn.: Duchesnea indica (Andrews) Focke) (Rosaceae)

Confirmation for the flora of Tenerife. Naturalized - invasive.

Spain, Tenerife: Taganana, vueltas de Taganana, 03.04.1972, T. Feremans s. n. (GENT); Forêt de Mercedes, près de la Casa Forestal à $5 \mathrm{~km}$ de 1'Emisora Forestal, talus de la route, 03.04.1972, J. Duvigneaud 72 Can 532 (BR); Parque Rural Anaga, Las Casas de la Cumbre, TF13 (between km 16-17), damp, shady rocks, locally, 12.09.2010, 
F. Verloove 8429 (ORT 41751); Ibid., s. d., M. A. Padrón-Mederos (ORT 38855).

Native to south and southeastern Asia. Widely cultivated as an ornamental (groundcover) and now naturalized and locally an invasive environmental weed in parts of Europe, the Americas and Australia.

Potentilla indica is surprisingly omitted in Hohenester \& Welss (1993) and Acebes-Ginovés et al. (2004, 2010), especially since it was already reliably recorded in Anaga Parque Rural ca. 40 years ago (see above and Santos-Guerra, 1988). In September 2010 its presence was confirmed twice: in Las Casas de la Cumbre and close to the Casa Forestal

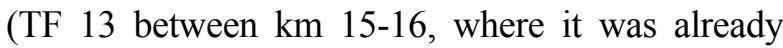
recorded in 1972). Potentilla indica always grows in damp, (half-) shady habitats, often under Laurus novocanariensis Rivas-Mart. et al., and accompanied by Erica spp., Rubus spp., etc. Up to the present, it still seems confined to paths close to habitations but future invasive behaviour is not unlikely.

Potentilla indica has been naturalized for quite some time in identical habitats in the Açores (Valentine, 1968) and Madeira (Press \& Short, 1994).

This species is usually referred to as Duchesnea indi$c a$ but recent molecular phylogenetic research strongly suggests its inclusion in Potentilla (Potter et al., 2007).

Pulicaria paludosa Link in Neues J. Bot. 1(3): 142 (1806)

(syn.: Pulicaria arabica (L.) Cass. subsp. hispanica (Boiss.) Murb.)

(Asteraceae)

New records for the flora of Tenerife. Naturalized (or possibly native?).

Spain, Tenerife: Las Cucharas, TF5 between San Juan de la Rambla and Icod, at Barranco de Las Ánimas, bare, gravelly (ruderal) area adjoining road towards Icod de Los Vinos, locally abundant, 07.09.2010, F. Verloove 8425 (ORT 41723, TFC).

Native to Spain, Portugal and Morocco (GamalEldin, 1981). Despite its weedy nature only rarely recorded outside its native distribution range, for instance in California (Raven, 1963).

Pulicaria paludosa was recently recognized for the first time from Tenerife where it has long been confused with $P$. vulgaris (Santos-Guerra \& Reyes-
Betancort in Greuter \& Raab-Straube, 2009, as $P$. arabica subsp. hispanica). In September 2010 it was recorded in two new localities: in relative abundance on bare, gravelly soil (parking place) by a road verge in Las Cucharas (see above) and furthermore in small number in Barranco de Santos in Santa Cruz (dry, gravelly riverbed). Pulicaria vulgaris is, indeed, rather similar but it has broader cauline leaves (lanceolate to elliptical vs. linear to narrowly oblong) with undulate margins and its achenes are appressed pubescent (vs. erecto-patent pubescence).

The residence status of Pulicaria paludosa in the Canary Islands is uncertain. It is now accepted as a possibly native species by Acebes-Ginovés et al. (2010). However, the oldest known records only date back to 1983 (Santos-Guerra \& ReyesBetancort in Greuter \& Raab-Straube, 2009) which rather suggest a fairly recent introduction.

Schefflera actinophylla (Endl.) Harms in Engl. \& Prantl, Nat. Pflanzenfam. 3(8): 36 (1894)

(syn.: Brassaia actinophylla Endl.)

(Araliaceae)

New to the flora of the Canary Islands. Ephemeral (?).

Spain, Tenerife: Puerto de la Cruz, surroundings of the Botanic Garden, epiphyte on Phoenix canariensis, 17.04.2011, J. A. Reyes-Betancort (ORT 41761, BR).

Native to southern New Guinea and North Australia (Govaerts, 2011a).

Introduced into the Canary Islands as a fastgrowing, flowering landscape tree. Seedlings probably came from gardens of nearby private residences. Its seeds - doubtlessly introduced via bird droppings - have found suitable conditions for germination below the crown of leaves of Phoenix canariensis.

Sclerophylax spinescens Miers in London J. Bot. 7: 19 (1848)

(Solanaceae)

New record of a recently introduced species to the flora of Tenerife. Naturalized (?).

Spain, Tenerife: Puerto de la Cruz, Muelle (port), at the lighthouse, ruderal area close to the sea, 
scattered specimens, 05.09.2010, F. Verloove 8443 (BR, ORT 41734).

Native to South America (Argentina, Uruguay). Initially hardly known as a weed outside its native distribution range (Di Fulvio, 1961) but recently apparently increasing, for instance in the Cape Verde Islands (Gonçalves, 2002). A record from Spain (1982, surroundings of Roquetas del Mar, prov. Almeria; see Kunkel, 1982) has largely been overlooked so far (compare with Dana et al., 2001).

The invasion history of Sclerophylax spinescens in the Canary Islands is rather well documented (Hansen, 1973; Hansen, 1975; Duvigneaud, 1979). Up to the present it was known from Gran Canaria (Hohenester \& Welss, 1993) and more recently also from Fuerteventura (Acebes-Ginovés et al., 2004, 2010) and Tenerife (Siverio-Núñez et al., 2011). It is here reported for the first time from the northern part of the island of Tenerife. Sclerophylax spinescens grows in small number at the foot of the lighthouse in the port of Puerto de la Cruz (bare, sandy, ruderal area). A further local extension in similar habitats, like in Gran Canaria, seems very likely.

Sechium edule (Jacq.) Sw., Fl. Ind. Occid. 2: 1150 (1800)

(Cucurbitaceae)

New to the flora of Tenerife. Naturalized.

Spain, Tenerife: Los Realejos, TF342, climbing in trees and adjacent arable land, invasive, 07.09.2010, F. Verloove 8432 (ORT 41742).

Native to tropical America. Widely cultivated for its fruits and tubers in many (sub-) tropical regions of the world (Mabberley, 2008), more rarely also as an ornamental (Cox, 1997). Sechium edule is also cultivated in the Iberian Peninsula (Castroviejo, 1993) but apparently not yet recorded as an escape.

In the Canary Islands Sechium edule is widely cultivated but, up to present, only reported as an escape from Gran Canaria (Hohenester \& Welss, 1993; Acebes-Ginovés et al., 2004). In Tenerife it is often seen but mostly in the vicinity of habitations and probably merely as a relic of cultivation. However, at least in the locality mentioned above Sechium edule occurs in abundance and obviously no longer associated with former cultivation. It climbs in trees and shrubs and extends to an adjacent agricultural field and behaves like an invasive weed.

In Madeira it was also reported as a relic of cultivation by Press \& Short (1994).

Solanum abutiloides (Griseb.) Bitter \& Lillo in Repert. Spec. Nov. Regni Veg. 12: 136 (1913)

(Solanaceae)

New to the flora of the Canary Islands. Naturalized.

Spain, Tenerife: Puerto de la Cruz, Barranco Martiánez, dry, gravelly riverbed, scattered specimens (in various stages of development), locally naturalized, 05.09.2010, F. Verloove 8475 (priv. herb. FV); Ibid., 03.06.2010, J. A. Reyes-Betancort \& M. A. PadrónMederos (ORT 41696).

Native to South America (Argentina and Bolivia). Exceptionally seen outside its original distribution range and apparently not cultivated as an ornamental. More or less naturalized in Nottingham (Great Britain), as a relic of former cultivation for phytochemical purposes (Shaw, 1995).

In Barranco Martiánez in Puerto de la Cruz Solanum abutiloides recently became naturalized (dry gravelly riverbed, steep talus slopes, etc.). In September $2010 \mathrm{ca}$. 15-20 plants were counted in various stages of development, some obviously many years old and copiously reproducing.

In general appearance Solanum abutiloides somehow looks like $S$. mauritianum Scop., another South American xenophyte and also well-established in Barranco Martiánez. Both are woody, unarmed species with entire leaves, relatively small flowers and further share very prominent axillary leaves (pseudo-stipules); they belong to section Brevantherum Seithe (Roe, 1972). Solanum abutiloides is easily distinguished from $S$. mauritianum by its very distinct odour (presence of scattered glandular hairs), deeply cordate leaves, hairs with relatively fewer, suberect branches, smaller habit $(100-300 \mathrm{~cm})$, etc.

The initial vector of introduction of Solanum abutiloides in Puerto de la Cruz is unknown. It has furthermore been recorded as a garden weed for quite a long time in the city of La Laguna (second author's obs.). 
Solanum villosum Mill., Gard. Dict., ed. 8, n. 2: 18 (1768)

subsp. miniatum (Bernh. ex Willd.) Edmonds in

Bot. J. Linn. Soc. 89(2): 166 (1984)

(syn.: S. alatum Moench)

(Solanaceae)

New records to the flora of Tenerife. Naturalized.

Spain, Tenerife: El Bailadero, TF12, road verge, few specimens, 14.03.2008, F. Verloove 7053 (BR, MA, TFC); Parque Rural Anaga, TF13 between km $11-12,+/$ - ruderal road verge, not rare in this area, 09.09.2010, F. Verloove 8440 (BR).

Native to Old World (warm-temperate and subtropical regions). Now a nearly cosmopolitan weed.

Hohenester \& Welss (1993) and Acebes-Ginovés et al. (2004) only cite this taxon from the islands of Gran Canaria and El Hierro (as Solanum alatum). Nevertheless it had already been recorded from Lanzarote by Berthelot (1840) and Menéndez et al. (1948) although, at present, it is relegated to a single locality (second author's obs.). Given its local abundance in parts of Tenerife it probably is a long neglected, older introduction. Especially in Parque Rural Anaga (González-González et al., 2002; see also Rodríguez-Navarro et al., 2010) it is not rare at all (usually confined to ruderal road verges, etc.).

Solanum villosum is a very variable species, usually divided into two distinct subspecies. The plants currently found in Tenerife are subglabrous and have sharply angled stems; they belong to subsp. miniatum. However, with respect to the number of flowers they markedly differ from the usual concept of Solanum villosum s.l.: inflorescences bear up to 10 or more flowers while few-flowered inflorescences (3-5; see for instance Hawkes \& Edmonds, 1972) are characteristic of genuine $S$. villosum. The taxonomic value of this aberration will require further study. Solanum patens Lowe, a very similar taxon endemic to Madeira (Press $\&$ Short, 1994), is now merely included in the synonymy of S. villosum s.l. (cf. www.solanaceaesource.org).

Sporobolus copei Verloove in Nordic J. Bot. 28(4): 465 (2010)

(Poaceae)

New records of a recently discovered species to the flora of Tenerife. Naturalized.
Spain, Tenerife: Las Mercedes, Parque Rural Anaga, close to the junction of TF12-TF143 ( $c a$. $\mathrm{km}$ 23.5), road verge, one dense clump, 09.09.2010, F. Verloove 8442 (BR, ORT 41722); Parque Rural Anaga, TF13 between km 14-15 (ca. 14.3), road verge, dense monospecific stand over $c a .30-35 \mathrm{~m}$, 12.09.2010, F. Verloove 8418 (BR, ORT 41727).

Origin unknown, possibly southeastern Africa (although Canarian endemism cannot be ruled out). Recently described as a species new to science from Tenerife (Verloove, 2010).

The above new records are an addition to those already published in Verloove (2010) and confirm the presence of Sporobolus copei throughout the Parque Rural Anaga. All populations are restricted to more or less bare and disturbed road verges. The newly discovered population by the TF13 (around $\mathrm{km}$ 14.3) seems to be the largest known so far.

In addition to the localities cited above, Sporobolus copei was furthermore seen (s.c.) along TF13 close to La Casa Forestal (few specimens).

The exact residence status of Sporobolus copei in Tenerife remains uncertain. However, it is very unlikely that it has been overlooked so far in Anaga Parque Rural: it grows by road verges in places that have been visited by botanists very frequently in the past. A relatively recent introduction still seems most feasible (see also Verloove, 2010).

Tradescantia zebrina Bosse, Vollst. Handb. B1.gärtn., ed. 2, 4: 655 (1849)

(syn.: Zebrina pendula Schnizl.)

(Commelinaceae)

New to the flora of Tenerife. Naturalized.

Spain, Tenerife: Parque Rural de Anaga, El Batán, 05.04.2011, J. A. Reyes-Betancort (ORT 41762, $\mathrm{BR})$.

Native from Mexico to Colombia (Govaerts, $2011 b$ ). Widely introduced in the tropics, either intentionally as an ornamental or unintentionally as a weed.

Tradescantia zebrina is frequently cultivated as an ornamental and it has previously been recorded as an escape from Gran Canaria and La Palma (Acebes-Ginovés et al., 2010). It is here reported for the first time from Tenerife as well. In El Batán 
it was observed for the first time in September 2010: few plants on the stony walls along the road, growing with Opuntia ficus-indica (L.) Mill. Tradescantia zebrina produces large amounts of viable cuttings.

Turnera ulmifolia L., Sp. P1. 1: 271 (1753) var. ulmifolia

(Passifloraceae)

New to the flora of Tenerife. Naturalized.

Spain, Tenerife: Puerto de la Cruz, Barranco Martiánez, dry, gravelly riverbed, old wall, two populations, one apparently well-established, 05.09.2010, F. Verloove 8439 (BR, ORT 41729).

Native to tropical America. Widely introduced in the tropics, either intentionally as an ornamental or unintentionally as a weed.

Turnera ulmifolia is frequently, at least in the last decade, cultivated as an ornamental in the Canary Islands. It was recently recorded as an escape from cultivation for Fuerteventura (Scholz et al., 2011). In Tenerife, it was observed twice in September 2010: few plants on the dry, gravelly riverbed and numerous plants on a wall adjoining Barranco Martiánez in Puerto de la Cruz. Turnera ulmifolia obviously produces large amounts of viable seed and a future naturalization seems very likely.

Turnera ulmifolia is a fairly variable species. The plants here concerned have leaves that are less hairy than usually is the case in var. ulmifolia (Arbo, 2005). However, the dissected and appendaged bracts clearly point to this variety.

Turnera was traditionally placed in the Turneraceae family. Although morphologically very different, recent molecular phylogenetic studies have transferred it to a broadly circumscribed Passifloraceae family (Mabberley, 2008).

\section{ACKNOWLEDGEMENTS}

The authors wish to express their gratitude to Dr. Sylvia Phillips (Kew Botanic Gardens, England) for revising our collection and providing interesting comments on Hyparrhenia rufa subsp. altissima. Also we would like to thank Dr. S. Pyke (Jardí Botànic de Barcelona) and an anonymous referee for their helpful comments on the manuscript.

\section{REFERENCES}

Acebes-Ginovés, J. R., del Arco Aguilar, M., García Gallo, A. et al. 2004. Pteridophyta, Spermatophyta. In: Izquierdo, I., Martín, J. L., Zurita, N. \& Arechavaleta, M. (Eds.), Lista de especies silvestres de Canarias (hongos, plantas y animales terrestres) 2004. Gobierno de Canarias: 96-143.

Acebes-Ginovés, J. R., León Arencibia, M. C., RodríguezNavarro, M. L. et al. 2010. Pteridophyta, Spermatophyta. In: Arechavaleta, M., Rodríguez, S., Zurita, N. \& García, A. (Eds.), Lista de especies silvestres de Canarias (hongos, plantas y animales terrestres). 2009. Gobierno de Canarias: 119-172.

Allen, C. M. \& Hall, D. W. 2003. Paspalum. In: Barkworth M. E., Capels, K. M., Long, S. \& Piep, M. B. (Eds.), Flora of North America north of Mexico 25. Oxford University Press, New York-Oxford: 566-599.

Allred, K. W. 2003. Bothriochloa. In: Barkworth M. E., Capels, K. M., Long, S. \& Piep, M. B. (Eds.), Flora of North America north of Mexico 25. Oxford University Press, New York-Oxford: 639-647.

APG III. 2009. An update of the Angiosperm Phylogeny Group classification for the orders and families of flowering plants. APG III. Bot. J. Linn. Soc. 161(2): 105-121.

Arbo, M. M. 2005. Systematic studies in Turnera (Turneraceae). III. Series Anomalae and Turnera. Bonplandia 14(3-4): 115-318.

Báez, M. 1998. Sobre la presencia del Himenóptero Polinizador de los "Laureles de Indias" en Canarias. Bol. Asoc. Esp. Ent. 22(1-2): 225.

Benítez-de-Lugo, N. \& Wildpret, G. 1879. Catálogo de las plantas que contiene el jardín de aclimatación de la Orotava, en Tenerife. La Orotava.

Berthelot, S. 1840. Géographie botanique (des Îles Canaries). In: Webb P. B. \& Berthelot, S., Hist. Naturelle des Îles Canaries 3(1). Béthune Ed., París.

Bleeker, W., Klausmeyer, S., Peintinger, M. \& Dienst, M. 2008. DNA sequences identify invasive alien Cardamine at Lake Constance. Biol. Conserv. 141: 692-698.

Brummitt, R. K. 1972. Heliotropium. In: Tutin, T. G., Heywood, V. H., Burges, N. A., Moore, D. M., Valentine, D. H., Walters, S. M. \& Webb, D. A. (Eds.), Flora Europaea 3. Cambridge University Press, Cambridge: 84-86.

Cabezudo, B., Casimiro-Soriguer Solanas, F., Pérez-Latorre, A. V., Dana, E. \& Ramírez, J. 2009. Hoffmannseggia glauca (Ortega) Einfer (Fabaceae, Caesalpinioideae) nuevo metáfito en el Sur de la Península Ibérica (Málaga, España). Acta Bot. Malac. 34: 261-263.

Castroviejo, S. 1990. Atriplex. In: Castroviejo, S., Laínz, M., López González, G., Montserrat, P., Muñoz-Garmendia, F., Paiva, J. \& Villar, L. (Eds.), Flora Ibérica 2. PlatanaceaePlumbaginaceae (partim). Real Jardín Botánico, CSIC, Madrid: 503-513.

Castroviejo, S. 1993. Cucurbitaceae. In: Castroviejo, S., Aedo, C., Cirujano, S. et al. (Eds.), Flora Ibérica 3. Plumbaginaceae (partim)-Capparaceae. Real Jardín Botánico, CSIC, Madrid: 454-470.

Celarier, R. P. \& Harlan, J. R. 1958. The cytogeography of the Bothriochloa ischaemum complex. Gramineae. I. Taxonomy, and geographic distribution. Bot. J. Linn. Soc. 55: 755-760.

Chandra, V. 1982. Merremia tuberosa (L.) Rendle: a new 
record for Uttar Pradesh. Indian Forester 108(9): 633-634.

Clayton, W. D. \& Renvoize, S. A. 1982. Gramineae (part 3). In: Polhill, R. M. (Ed.), Flora of Tropical East Africa. A. A. Balkema, Rotterdam: 451-898.

Conti, F., Abbate, G., Alessandrini, A. \& Blasi, C. (Eds.) 2005. An annotated checklist of the Italian vascular flora. Palombi Editori, Roma.

Cox, C. J. 1997. Sechium. In: Cullen, J., Knees, S. G. \& Cubey, H. S. (Eds.), The European Garden Flora 5. Cambridge University Press, Cambridge: 296-297.

Cruz-Trujillo, G. M., Rodríguez Delgado, O. \& Wildpret de La Torre, W. 2008. Dichanthium annulatum (Forssk.) Stapf, una gramínea nueva para las islas canarias. Bot. Macaronés. 27: 137-140.

Dana, E., Cerrillo, M. I., Sanz-Elorza, M., Sobrino, E. \& Mota, J. F. 2001. Contribución al conocimiento de las xenófitas en España: catálogo provisional de la flora alóctona de Almería. Acta Bot. Malac. 26: 264-276.

Dana, E., Randall, R. P., Sanz-Elorza, M. \& Sobrino, E. 2003. First evidence of the invasive behaviour of Leucaena leucocephala in Europe. Oryx 37(1): 14.

Di Fulvio, T. E. 1961. El género Sclerophylax (Solanaceae). Kurtziana 1: 9-104.

Dixon, D. J., Jackes, B. R. \& Bielig, L. M. 2001. Figuring out the Figs: the Ficus obliqua-Ficus rubiginosa Complex (Moraceae: Urostigma sect. Malvanthera). Telopea 14: 133-154.

Duvigneaud, J. 1979. Sclerophylax spinescens Miers. In: Notes brèves sur certaines centuries distribuées dans le fascicule 17. Bull. Soc. Échange Pl. Vasc. Eur. Occ. Bassin Médit. 17: 44-45.

Eriksson, O., Hansen, A. \& Sunding, P. 1974. Flora of Macaronesia. Check-list of vascular plants. Department of Biology, University of Umeå, Umeå.

Gamal-Eldin, E. 1981. Revision der Gattung Pulicaria (Compositae - Inuleae) für Afrika, Makaronesien und Arabien. J. Cramer, Vaduz.

George, A. S. (Ed.) 1984. Flora of Australia 4 (Phytolaccaceae to Chenopodiaceae). Australian Govt. Pub. Service, Canberra.

Gonçalves, A. E. 2002. 71. Solanaceae. In: Paiva J. (Ed.), Flora de Cabo Verde, plantas vasculares. Praia, Lisboa: 73.

Gonçalves, M. L. 1996. 72. Convolvulaceae. In: Paiva J. (Ed.), Flora de Cabo Verde, plantas vasculares. Praia, Lisboa: 41.

González-González, R., León Arencibia, M. C. \& Del-Arco, M. 2002. Los Helechos de la Reserva Natural Integral de El Pijaral. Consejería de Política Territorial y Medio Ambiente del Gobierno de Canarias, S/C de Tenerife.

Govaerts, R. 2011a. World Checklist of Araliaceae. The Board of Trustees of the Royal Botanic Gardens, Kew. Retrieved April 20, 2011, from http://www.kew.org/wcsp/

Govaerts, R. 2011b. World Checklist of Commelinaceae. The Board of Trustees of the Royal Botanic Gardens, Kew. Retrieved April 20, 2011, from http://www.kew.org/wcsp/

Greuter, W. \& Raab-Straube, E. V. 2009. Euro+Med notulae, 4. Willdenowia 39: 327-333.

Greuter, W. \& Raus, Th. (Eds.) 2005. Med-Checklist Notulae, 23. Willdenowia 35: 55-64.

Hansen, A. 1971. Floristic notes from the Canary Islands (mostly Tenerife). Cuad. Bot. Canaria 13: 1-7.

Hansen, A. 1973. Some floristic notes from Gran Canaria.
Cuad. Bot. Canaria 18-19: 39-41.

Hansen, A. 1975. Contributions to the flora of the Canary Islands. Cuad. Bot. Canaria 25: 3-14.

Hansen, A. \& Sunding, P. 1993. Flora of Macaronesia. Checklist of vascular plants ( $4^{\text {th }}$ revised edition). Sommerfeltia 17: 1-295.

Hawkes, J. G. \& Edmonds, J. M. 1972. Solanum. In: Tutin, T. G., Heywood, V. H., Burges, N. A., Moore, D. M., Valentine, D. H., Walters, S. M. \& Webb, D. A. (Eds.), Flora Europaea 3. Cambridge University Press, Cambridge: 197-199.

Heim, G. 1984. Die Compositen-Gattungen Conyza, Blumea und Pluchea auf den Kapverdischen Inseln (Phanerogamae: Asteraceae). Courier Forschungsinst. Senckenberg 68: $143-178$.

Herrero-Borgoñón, J. J. 2007. Dos Mimosoideas (Leguminosae) nuevas para la flora castellonense. Flora Montiber. 37: 26-28.

Hohenester, A. \& Welss, W. 1993. Exkursionsflora für die Kanarischen Inseln. Verlag Eugen Ulmer, Stuttgart.

Hughes, C. 1998. Monograph of Leucaena (LeguminosaeMimosoideae). Syst. Bot. Monogr. 55: 1-244.

Hyam, R. D. 2000. Merremia. In: Cullen, J., Alexander, J. C. M., Brickell, C. D. et al. (Eds.), The European Garden Flora 6. Cambridge University Press, Cambridge: 115.

Joel, D. M. \& Liston, A. 1986. New adventive weeds in Israel. Israel J. Bot. 35: 215-223.

King-Jones, S. 2001. Revision of Pluchea Cass. (Compositae, Plucheeae) in the Old World. Englera 23: 1-136.

Kodela, P. G. \& Tindale, M. D. 2001. Mimosaceae (Acacia Part I). In: Flora of Australia 11A. CSIRO Publishing, Melbourne: 1-552.

Kunkel, G. 1982. Sobre Periploca angustifolia, y notas sobre algunas plantas forasteras en la flora de Almería, España. Paralelo: 53-57.

Lejoly, J. \& Lisowski, S. 1992. Les genres Merremia et Ipomoea (Convolvulaceae) dans la Flore d'Afrique Centrale (Zaïre, Rwanda, Burundi). Fragm. Florist. Geobot. 37(1): 21-125.

Lihová, J., Marhold, K., Kudoh, H. \& Koch, M. A. 2006. Worldwide phylogeny and biogeography of Cardamine flexuosa (Brassicaceae) and its relatives. Amer. J. Bot. 93(8): 1206-1221.

Lobin, W. 1982. Additions and corrections to: O. Eriksson, A. Hansen \& P. Sunding - Flora of Macaronesia. Checklist of Vascular Plants, $2^{\text {nd }}$ revised edition - II. Garcia de Orta, Sér. Bot. 5(2): 213-224.

Mabberley, D. J. 2008. Mabberley's plant-book (3th ed.). Cambridge University Press, Cambridge.

Macdougal, J. M. 1994. Revision of Passiflora subgenus Decaloba section Pseudodysosmia (Passifloraceae). Syst. Bot. Monogr. 41: 1-146.

Marchante, E., Freitas, H. \& Marchante, H. 2008. Guia Prático para a Identificação de Plantas Invasoras de Portugal Continental. Universidade de Coimbra, Coimbra.

Menéndez, G., Sventenius, E. R. S., Bolinaga, J. \& González, C. 1948. Index Seminum quae Hortus Acclimatationis Plantarum Arautapae. Agron. Invest. Hisp. Inst. [Inst. Nat. Invest. Agron.]. Jardín de Aclimatación de Plantas de la Orotava, Puerto de la Cruz, Tenerife 1: 3-12.

Miller, D. M. 1997. Passiflora. In: Cullen, J., Knees, S. G. \& Cubey, H. S. (Eds.), The European Garden Flora 5. Cambridge University Press, Cambridge: 258-262.

Montelongo-Parada, V. 1996. Los Laureles de Indias de Ca- 
narias comienzan a reproducirse por sí solos. Noticias del Museo Canario 7 (Julio 1994-Diciembre 1995): 10-11.

Padrón-Mederos, M. A., Guma, I. R., Santos-Guerra, A. \& Reyes-Betancort, J. A. 2009. Apuntes florísticos y taxonómicos para la flora de las Islas Canarias. Acta Bot. Malac. 34: 242-251.

Padrón-Mederos, M. A., Reyes-Betancort, J. A., González González, R. \& León Arencibia, M. C. 2007. Adiciones y comentarios a la flora vascular de Canarias. Vieraea 35: 43-50.

Paiva, J. 1999. Acacia. In: Talavera, S., Aedo, C., Castroviejo, S., Romero, C., Sáez, L., Salgueiro, F. J. \& Velayos, M. (Eds.), Flora Iberica 7(1). Real Jardín Botánico, CSIC, Madrid: 11-25.

Phillips, S. 1995. Poaceae (Gramineae). In: Hedberg, I. \& Edwards, S. (Eds.), Flora of Ethiopia and Eritrea. The National Herbarium, Addis Ababa University \& Department of Systematic Botany, Uppsala University, Addis Ababa (Ethiopia) and Uppsala (Sweden).

Portal, R. 2002. Eragrostis de France et de l'Europe Occidentale. Vals-près-Le Puy, France.

Potter, D., Eriksson, T., Evans, R. C. et al. 2007. Phylogeny and classification of Rosaceae. Pl. Syst. Evol. 266: 5-43.

Press, J. R. \& Short, M. J. 1994. Flora of Madeira. The Natural History Museum, London.

Pyke, S. 2003. Catálogo florístico de las plantas vasculares de Zaragoza. Publicaciones del Consejo de Protección de la Naturaleza de Aragón, Zaragoza.

Pyke, S. 2008. Contribución al conocimiento de la flora alóctona catalana. Collect. Bot. (Barcelona) 27: 95-104.

Raimondo, F. M. \& Domina, G. 2007. Two new Mimosaceae naturalized in Italy. Fl. Medit. 17: 209-216.

Raven, P. H. 1963. Pulicaria hispanica (Compositae: Inuleae), a new weed to California. Aliso 5: 251-253.

Reyes-Betancort, J. A., León Arencibia, M. C. \& Wildpret de La Torre, W. 2000. Adiciones a la flora vascular de la isla de Lanzarote (islas Canarias). III. Vieraea 28: 39-49.

Richardson, D. M., Pyšek, P., Rejmánek, M., Barbour, M. G., Panetta, F. D. \& West, C. J. 2000. Naturalization and invasion of alien plants: concepts and definitions. Diversity and Distrib. 6: 93-107.

Rodríguez-Navarro, M. L., Lucía Sauquillo, V. L., AcebesGinovés, J. R. \& Pérez de Paz, P. L. 2010. Contribución al conocimiento de la flora vascular del municipio de El Sauzal (Tenerife, Islas Canarias). Vieraea 38: 63-82.

Rodríguez-Pérez, J. A. 1998. Flore exotique des Îles Canaries. Editorial Everest, S.A., León.

Roe, K. E. 1972. A revision of Solanum section Brevantherum (Solanaceae). Brittonia 24: 239-278.

Santos-Guerra, A. 1988. Notas Corológicas II: Adiciones florísticas y nuevas localidades para la flora canaria. Homenaje a Pedro Montserrat. CSIC, Jaca, Huesca: 347-349.

Sanz-Elorza, M., Dana, E. \& Sobrino, E. 2001. Aproximación al listado de plantas alóctonas invasoras reales y potenciales en España. Lazaroa 22: 121-131.
Sanz-Elorza, M., Dana, E. D. \& Sobrino, E. 2004. Atlas de las plantas alóctonas invasoras en España. Dirección General para la Biodiversidad, Madrid.

Sanz-Elorza, M., Dana, E. D. \& Sobrino, E. 2005. Aproximación al listado de plantas alóctonas invasoras reales y potenciales en las islas Canarias. Lazaroa 26: 55-66.

Scholz, S., Reyes-Betancort, J. A. \& Wildpret de La Torre, W. 2011. Adiciones a la flora vascular de Fuerteventura (Islas Canarias). III. Bot. Macaronés. 28 (in press).

Shaw, J. M. H. 1995. Another alien Solanum (S. abutiloides). BSBI News 70: 34-35.

Siverio-Núñez, A., Sobrino, E., Rodríguez de La Torre, H. A., Reyes-Betancort, J. A. \& Santos-Guerra, A. 2011. Nuevos Xenófitos de elevada capacidad invasora para la Flora Canaria. Bot. Macaronés. 28 (in press).

Simon, B. K. 1989. Studies in Australian grasses: 4. Taxonomic and nomenclatural studies in Australian Andropogoneae. Austrobaileya 3(1): 79-99.

Ulmer, T. \& Macdougal, J. M. 2004. Passiflora. Passionflowers of the world. Timber Press, Portland.

Valentine, D. H. 1968. Duchesnea. In: Tutin, T. G., Heywood, V. H., Burges, N. A., Moore, D. M., Valentine, D. H., Walters, S. M. \& Webb, D. A. (Eds.), Flora Europaea 2. Cambridge University Press, Cambridge: 48.

Vega, A. S. 2000. Revisión taxonómica de las especies americanas del género Bothriochloa (Poaceae: Panicoideae: Andropogoneae). Darwiniana 38(1-2): 127-186.

Verloove, F. 2003. Physalis ixocarpa Brot. ex Hornem. and Verbena litoralis Kunth, new Spanish xenophytes and records of other interesting alien vascular plants in Catalonia (Spain). Lazaroa 24: 7-11.

Verloove, F. 2005. New records of interesting xenophytes in Spain. Lazaroa 26: 141-148.

Verloove, F. 2008. Studies within the genus Digitaria Haller (Poaceae, Panicoideae) in southwestern Europe. Candollea 63(2): 227-233.

Verloove, F. 2010. Sporobolus copei sp. nov. (Poaceae: Chloridoideae) from Tenerife (Canary Islands, Spain). Nordic J. Bot. 28: 465-468.

Verloove, F. \& Sánchez-Gullón, E. 2008. New records of interesting xenophytes in the Iberian Peninsula. Acta Bot. Malac. 33: 1-21.

Webb, D. A. 1964. Phytolacca. In: Tutin, T. G., Heywood, V. H., Burges, N. A., Valentine, D. H., Walters, S. M. \& Webb, D. A. (Eds.), Flora Europaea 1. Cambridge University Press, Cambridge: 112.

Zuloaga, F. O., Morrone, O., Davidse, G., Filgueiras, T. S., Peterson, P. M., Soreng, R. J. \& Judziewicz, E. 2003. Catalogue of New World Grasses (Poaceae): III. Subfamilies Panicoideae, Aristidoideae, Arundinoideae, and Danthonioideae. Contr. U. S. Natl. Herb. 46: 1-662.

Zuloaga, F. O., Pensiero, J. \& Morrone, O. 2004. Systematics of Paspalum Group Notata (Poaceae-Panicoideae-Paniceae). Syst. Bot. Monogr. 71: 1-75. 